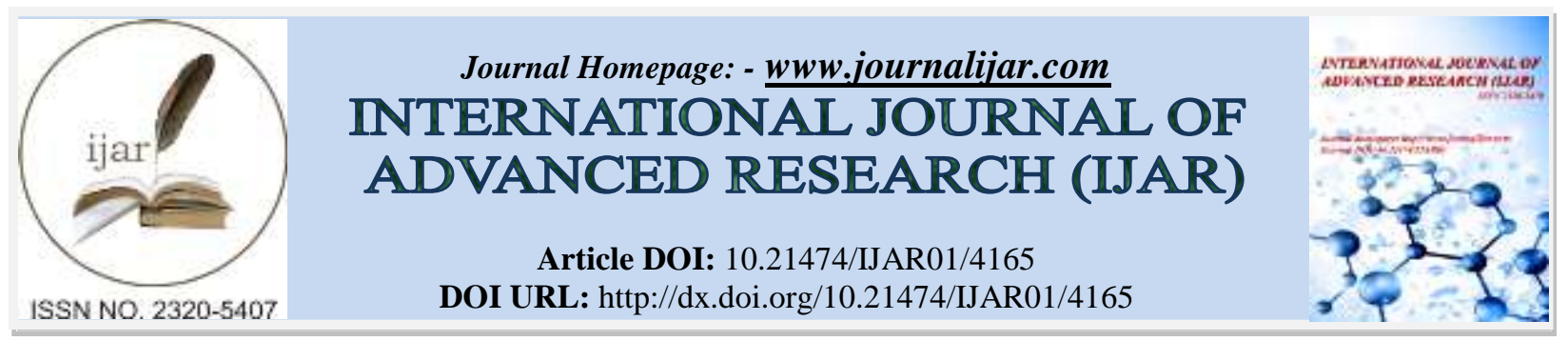

RESEARCH ARTICLE

\title{
NORMAL REFERENCE RANGES FOR SERUM URIC ACID IN POPULATION OF NORTH BIHAR
}

\section{Dr Talat Fatma (M.D) ${ }^{1}$, Dr Nishi (M.D) ${ }^{2}$, Dr Shamim Khurrum Azmi (M.S) ${ }^{3}$ and Dr Ajit Kumar Chaudhary (M.D) ${ }^{4}$}

1. Assistant Professor, Department of Pathology, Darbhanga Medical College, Darbhanga.

2. Tutor, AIIMS, Patna.

3. Senior Resident, Department of surgery, Darbhanga Medical College, Darbhanga.

4. Professor and H.O.D, Department of Pathology, Darbhanga Medical College, Darbhanga.

\section{Manuscript Info}

[.........................

Manuscript History

Received: 17 March 2017

Final Accepted: 14 April 2017

Published: May 2017

\section{Abstract}

Aim: To establish the reference range of serum uric acid levels in this population among healthy individuals.

Design: Prospective study done at Darbhanga Medical College, Bihar from December 2006- January 2009.

Materials and Methods:

1000 individuals above 30 years of age were included in the study. There were equal no of males and females.55\%(n=550) were vegetarians and $45 \%(n=450)$ were non vegetarians. $45 \%(n=450)$ were of low socioeconomic group, $40 \%(\mathrm{n}=400)$ were of middle socioeconomic group and $15 \%(\mathrm{n}=150)$ were of high socioeconomic group.70.2\%(n=702) were of normal weight, $19.8 \%(\mathrm{n}=198)$ were overweight, $5.3 \%(\mathrm{n}=53)$ were underweight and $3.7 \%(\mathrm{n}=37)$ were obese.

Serum uric acid was estimated by modified phototungstate method, end point assay.

The values of serum uric acid were statistically analyzed in relation to age, sex, BMI, socio economic group and eating habits.

Results:-

- The observed reference range of uric acid in the population in male is $3.5-6.5 \mathrm{mg} \%$ and in females is $2.5-6 \mathrm{mg} \%$.

- The mean serum uric acid in males was $4.959 \pm 1.029$ and in females $3.99 \pm$ 1.042.There is significant difference $(\mathrm{t}=11.07, \mathrm{p}<0.001)$

- Mean serum uric acid in non vegetarians was slightly higher than vegetarians but not significant $(\mathrm{t}=1.48, \mathrm{p}>0.05)$

- Serum uric acid was significantly higher in overweight and obese $(\mathrm{t}=11.07), \mathrm{p}<0.001)$ in comparison to underweight and normal weight.

- Serum uric acid was higher in high socioeconomic strata compared to low socioeconomic group $(\mathrm{t}=10.42, \mathrm{p}<0.001)$. 


\section{Introduction:-}

Serum uric acid concentrations are distributed in community as continuous variable and are determined by a number of demographic factors of which age, sex, body mass index, nature of diet, and socioeconomic class are most important. Serum uric acid levels are positively correlated with intelligent social class, weight, alcohol consumption and high protein diet. Also it has positive correlation with hyperlipidaemia, atherosclerosis, diabetes mellitus, kidney disease, primary hypertension and as component of metabolic syndrome.

It is interesting to study the uric acid levels in our population which has not been done extensively. In western world men have mean serum uric acid values of $6.8 \mathrm{mg} / \mathrm{dL}$, and women have mean serum uric acid values of $6 \mathrm{mg} / \mathrm{dL}$. In our population mean serum uric acid levels in male is $4.9 \mathrm{mg} / \mathrm{dl}$ and in women is $3.9 \mathrm{mg} / \mathrm{dl}$ both of which is significantly lower than the western world. This implies that serum uric acid depends on divergent factors like demographic factors and various metabolic states.

So the normal reference range of serum uric acid has been reported to be different in different populations by different workers at different places.

The present work aims at estimation of serum uric acid levels in adult population (over 30 years) so that we can suggest the normal reference range of serum uric acid in population of North Bihar.

\section{Material and Methods:-}

\section{Material:-}

The people were selected from general staff of Darbhanga Medical College and also from the healthy relatives of patients presenting at Darbhanga Medical College and Hospital. Their age was above 30 yrs and they were from both sexes. All of them were screened for renal function and those with impaired renal function were excluded as that would impair uric acid excretion.

A large no of cases were taken to increase the specificity and to establish the normal reference range of uric acid in this region which includes a large population.

\section{Sampling:-}

Unhaemolysed serum or plasma was used in case of plasma EDTA was used as anticoagulant. Sample was taken after $12 \mathrm{hrs}$ of overnight fasting. Serum and plasma were prepared by centrifugation at $3000 \mathrm{rpm}$ for 15 minutes and analysis was done within 2 hrs of collection.

\section{Methods:-}

Serum uric acid was estimated by modified phototungstate method, end point assay.

\section{Principle:-}

In alkaline medium uric acid in the sample reduces phototungstate to produce tungstate blue colour. Absorbance of coloured compound is measured at $660 \mathrm{~nm}$ and is directly proportional to the amount of uric acid concentration in the sample. This method uses a special surfactant, which eliminates sample deproteinisation step prior to analysis.

Uric acid + phototungstate $=$ tungstate blue colour

\section{Statistical Calculation:-}

The values of serum uric acid were statistically analyzed by determining the mean, standard deviation (S.D), Standard Error of Mean (S.E.M), t value, $\mathrm{p}$ value. All statistical tests were 2 -sided and a $P<0.05$ was recognized as the statistically significant.

\section{Observation and Results:-}

The study group included 1000 healthy individuals above 30 years of age and with no renal impairment. 
Table no 1:- Showing age distribution of study group.

\begin{tabular}{|c|c|c|c|c|}
\hline \multirow{2}{*}{ Age group(years) } & \multicolumn{2}{|c|}{ MALE } & \multicolumn{2}{c|}{ FEMALE } \\
\cline { 2 - 5 } & Number & Percentage & Number & Percentage \\
\hline $30-39$ & 105 & 21 & 195 & 16 \\
\hline $40-49$ & 180 & 36 & 125 & 39 \\
\hline $50-59$ & 115 & 23 & 70 & 25 \\
\hline $60-69$ & 65 & 13 & 30 & 14 \\
\hline 70 and above & 35 & 7 & 6 \\
\hline
\end{tabular}

Table no 2:- Showing serum uric acid levels in 500 males and 500 females among general healthy population

\begin{tabular}{|c|c|c|c|c|}
\hline Serum uric acid levels(mg\%) & \multicolumn{2}{|c|}{ MALES } & \multicolumn{2}{c|}{ FEMALES } \\
\cline { 2 - 5 } & Number of case & Percentage & Number of case & Percentage \\
\hline$<3$ & 5 & 1 & 17 & 3.4 \\
\hline $3-3.9$ & 50 & 10 & 100 & 20 \\
\hline $4-4.9$ & 230 & 46 & 190 & 38 \\
\hline $5-5.9$ & 150 & 30 & 160 & 32 \\
\hline $6-6.9$ & 40 & 8 & 25 & 5 \\
\hline $7-7.9$ & 15 & 3 & 5 & 1 \\
\hline $8-8.9$ & 10 & 2 & 3 & 0.6 \\
\hline
\end{tabular}

Table no 3:- Showing mean serum uric acid levels.

\begin{tabular}{|c|c|c|c|c|c|c|}
\hline \multirow[t]{2}{*}{ Group of subjects } & \multirow[t]{2}{*}{ No of cases } & \multicolumn{3}{|c|}{ Serum uric acid in $\mathrm{mg} / 100 \mathrm{ml}$} & \multirow{5}{*}{$\begin{array}{l}\text { t value } \\
\text { Between the } \\
\text { means of } \\
\text { males and } \\
\text { females } 14.75\end{array}$} & \multirow{3}{*}{$\begin{array}{l}\text { P value } \\
<0.001 \\
\text { Significant }\end{array}$} \\
\hline & & Mean & S.D. & S.E.M. & & \\
\hline Both sexes & 1000 & 4.48 & 1.035 & 0.040 & & \\
\hline Males & 500 & 4.95 & 1.029 & 0.046 & & \\
\hline Females & 500 & 3.99 & 1.042 & 0.047 & & \\
\hline
\end{tabular}

The mean serum uric acid in 1000 healthy individuals was $4.48 \pm 1.035$.

The mean serum uric acid in male was $4.65 \pm 1.029$ which was significantly higher than that of females $(3.94$ \pm 1.042 ).

Table no 4:- Showing serum uric acid levels in relation to socioeconomic status.

\begin{tabular}{|c|c|c|c|c|c|c|c|}
\hline \multirow{2}{*}{$\begin{array}{l}\text { Socioeconomic } \\
\text { status }\end{array}$} & \multirow{2}{*}{$\begin{array}{l}\text { No of } \\
\text { cases }\end{array}$} & \multirow[t]{2}{*}{ Percentage } & \multicolumn{3}{|c|}{ Serum uric acid $(\mathrm{mg} / \mathbf{1 0 0 m l})$} & \multirow[t]{2}{*}{ t value } & \multirow[t]{2}{*}{$P$ value } \\
\hline & & & Mean & S.D & SEM & & \\
\hline High & 150 & 15 & 5.28 & 1.32 & $\mathbf{1 . 1 0 7}$ & 10.42 & $<0.001$ significant \\
\hline Middle & 400 & 40 & 4.67 & $\mathbf{1 . 1 4 5}$ & 0.062 & 4.96 & $<0.001$ significant \\
\hline Low & 450 & 45 & 4.09 & 0.890 & 0.040 & 7.86 & $<0.001$ significant \\
\hline
\end{tabular}

Table no 5:- Showing serum uric acid in relation to body mass index ( BMI).

\begin{tabular}{|c|c|c|c|c|c|c|c|}
\hline \multirow{2}{*}{$\begin{array}{l}\text { Body weight based } \\
\text { on BMI }\end{array}$} & \multirow{2}{*}{$\begin{array}{l}\text { No of } \\
\text { cases }\end{array}$} & \multirow[t]{2}{*}{ Percentage } & \multicolumn{3}{|c|}{ Serum uric acid $(\mathrm{mg} / \mathbf{1 0 0 m l})$} & \multirow[t]{2}{*}{ t value } & \multirow[t]{2}{*}{$P$ value } \\
\hline & & & Mean & S.D & S.E.M & & \\
\hline $\begin{array}{l}\text { Underweight } \\
(17-19)\end{array}$ & 53 & 5.3 & 3.75 & 0.90 & 0.123 & 4.15 & $\begin{array}{l}<0.001 \\
\text { (significant) }\end{array}$ \\
\hline $\begin{array}{l}\text { Normal weight } \\
(20-24)\end{array}$ & 702 & 70.2 & 4.27 & 0.95 & $\mathbf{0 . 0 3 6}$ & 8.56 & $\begin{array}{l}<0.001 \\
\text { (significant) }\end{array}$ \\
\hline $\begin{array}{l}\text { Overweight } \\
(25-28)\end{array}$ & 198 & 19.8 & 5.03 & 1.20 & 0.085 & 11.07 & $\begin{array}{l}<0.001 \\
\text { (significant) }\end{array}$ \\
\hline Obese (29+) & 37 & 3.7 & 6.54 & 1.35 & 0.222 & 13.09 & $\begin{array}{l}<0.001 \\
\text { (significant) }\end{array}$ \\
\hline
\end{tabular}


Table No 6:- Showing serum uric acid in relation to eating habits

\begin{tabular}{|c|c|c|c|c|c|c|c|}
\hline \multirow[t]{2}{*}{ Eating habits } & \multirow[t]{2}{*}{$\begin{array}{ll}\text { No } & \text { of } \\
\text { cases } & \end{array}$} & \multirow[t]{2}{*}{ Percentage } & \multicolumn{3}{|c|}{$\begin{array}{l}\text { Serum uric acid } \\
(\mathrm{mg} / 100 \mathrm{ml})\end{array}$} & \multirow[t]{2}{*}{ t value } & \multirow[t]{2}{*}{ P value } \\
\hline & & & Mean & S.D & S.E.M & & \\
\hline Vegetarian & 550 & 55 & 4.43 & 1.047 & 0.045 & \multirow[t]{2}{*}{1.48} & \multirow{2}{*}{$\begin{array}{c}0.05 \\
\quad \text { (not } \\
\text { significant) }\end{array}$} \\
\hline Non vegetarian & 450 & 45 & 4.54 & 1.247 & 0.059 & & \\
\hline
\end{tabular}

\section{Summary and Conclusion:-}

The present work "Normal Reference Ranges for Serum Uric Acid In population of North Bihar" has been done on 1000 subjects.

- The summary of the work is as follows: The observed reference range of uric acid in the population in male is $3.5-6.5 \mathrm{mg} \%$ and in females is $2.5-6 \mathrm{mg} \%$.

- The mean of serum uric acid level in our population is $4.48 \pm 1.035$

- The mean serum uric acid in males was $4.959 \pm 1.029$ and in females $3.99 \pm 1.042$.There is significant difference $(\mathrm{t}=11.07, \mathrm{p}<0.001)$.

- Mean serum uric acid in non vegetarians was slightly higher than vegetarians but not significant $(\mathrm{t}=1.48, \mathrm{p}>0.05)$

- Serum uric acid was significantly higher in overweight and obese $(t=11.07), p<0.001)$ in comparison to underweight and normal weight.

- Serum uric acid was higher in high socioeconomic strata compared to low socioeconomic group ( $\mathrm{t}=10.42, \mathrm{p}$ $<0.001)$.

So we propose that every community should decide their own normal reference range.

We propose the following reference range of serum uric acid in population of north Bihar:

Males:-

- $\quad 3.5-6.5 \mathrm{mg} \%$ (normal)

- $\quad 6.6-7 \mathrm{mg} \%$ (high normal)

- $\quad>7 \mathrm{mg} \%$ ( hyperuricaemia)

Females:-

- $\quad 2.5-6 \mathrm{mg} \%$ (normal)

- $\quad 6.1-6.5 \mathrm{mg} \%$ (high normal)

- $\quad>6.5 \mathrm{mg} \%$ (hyperuricaemia)

We also recommend that further work, based upon screening of more subjects, on multicentric field study should be undertaken to reach more precise consensus on the debatable topic.

\section{Conflicts Of Interest:-}

The authors declare that there is no conflict of interests regarding the publication of this paper.

\section{References:-}

1. Prevalence of Gout and Hyperuricaemia in the US General Population The National Health and Nutrition Examination Survey 2007-2008 Yanyan Zhu,1 Bhavik J. Pandya,2 and Hyon K. Choi1

2. Medscape, an online website

3. M. D. Gardner and R. Scott, "Age- and sex-related reference ranges for eight plasma constituents derived from randomly selected adults in a Scottish new town," Journal of Clinical Pathology, vol. 33, no. 4, pp. 380-385, 1980.

4. A. H. Reed, D. C. Cannon, J. W. Winkelman, Y. P. Bhasin, R. J. Henry, and V. J. Pileggi, "Estimation of normal ranges from a controlled sample survey. I. Sex- and age-related influence on the SMA 12-60 screening group of tests," Clinical Chemistry, vol. 18, no. 1, pp. 57-66, 1972.

5. C. Bengtsson and E. Tibblin, "Serum uric acid levels in women: an epidemiological survey with special reference to women with high serum uric acid values,"Acta Medica Scandinavica, vol. 196, no. 1-2, pp. 93-102, 1974

6. Das M, Saikia M. Estimation of lipid profile in Assamese population. Indian Journal of Clinical Biochemistry, 2009; 24 (2) 190-193. 
7. R. Dybkaer and R. Grsbeck, "Theory of reference values," Scandinavian Journal of Clinical \& Laboratory Investigation, vol. 32, pp. 1-7, 1973.

8. Madhumita Das, N. C. Borah, M. Ghose, and N. Choudhury -Reference Ranges for Serum Uric Acid among Healthy Assamese PeopleS.

9. Winsten, "The ecology of normal values in clinical chemistry," CRC Critical Reviews in Clinical Laboratory Sciences, vol. 6, no. 4, pp. 319-330, 1976.

10. A. Alimonti, B. Bocca, E. Mannella et al., "Assessment of reference values for selected elements in a healthy urban population," Annali dell'Istituto Superiore di Sanita, vol. 41, no. 2, pp. 181-187, 2005. 